\title{
MORPHOLOGICAL VARIABILITY AND SEXUAL DIMORPHISM OF NOBLE CRAYFISH Astacus astacus FROM THE BALKANA LAKE
}

\author{
RAJKO ROLJIĆ ${ }^{1}$, VERA NIKOLIĆ ${ }^{2}$, NEBOJŠA SAVIĆ ${ }^{3}$ \\ ${ }^{1}$ Genetic Resources Institute University City, University of Banja Luka, Banja Luka, Bosnia and Herzegovina \\ ${ }^{2}$ Faculty of Biology, University of Belgrade, Beograd, Serbia \\ ${ }^{3}$ Faculty of Agriculture University City, University of Banja Luka, Banja Luka, Bosnia and Herzegovina
}

\begin{abstract}
This paper presents the information about morphological variability and sex dimorphism of the Noble crayfish (Astacus astacus) in the area of the Balkana Lake in Mrkonjic Grad. The crayfish were caught by hand made baited traps from October 9nd 2018. until May 31th 2019. A total of 58 crayfish were caught, of which 38 males and 20 females. The eight morphometric characteristics: body weight $(W)$, body length (TBL), claw length (CLL), cephalothorax length (CFL), carapace width (CPW), abdomen length (ABL), rostrum length (ROL) and rostrum width (ROW) were measured, both in males and females. Also, the body condition was determined for all specimens. The results of morphometric characteristics partially matched into the already known range of variations. These data represent first ones for the observed area. The $t$-test showed that there were significant differences between the sexes in W, TBL, CLL, CFL and CPW which are explained by the emphasized sex dimorphism of the noble crayfish.
\end{abstract}

Keywords: Noble crayfish, Morphometric features, Sex dimorphism, The Balkana Lake.

\section{INTRODUCTION}

The morphometric features of crayfish are the basic criteria for specifying the taxonomic status of the species. Precise crayfish taxonomy involves the application of these methods combined with anatomical, morphological, cytogenetic, biochemical, physiological, ecological, evolutionary, and other methods (Vukovic et al., 1978). A study of morphometric features of certain crayfish species from various water ecosystems to determine their systematic position and status was conducted by numerous authors such as Trozic-Borovac et al. (2007), Trozic-Borovac (2012a, 2012b) and Rajkovic (2012). Maguire (2010) emphasizes the importance of research of morphometric feature variability in species from the genus Astacus and Austropotamobius in order to produce an efficient key for determination, given the present difficulties in determination thereof.

There is a lack of information available of morphometric features of for species Astacus astacus from numerous places within their distribution area. The Noble crayfish lives in rivers and lakes with muddy or gravel bed, and seeks for the shelter by the coast covered with aquatic vegetation, or digs the holes (Maguire, 2010). This species is present and dominate in Bosnia and Herzegovina (Trozic-Borovac, 2011) and neighboring countries such as Serbia (Simic et al., 2008), Croatia (Maguire \& Gottstein-Matocec, 2004), Montenegro (Rajkovic, 2012) and Kosovo and Metochia (Zivic et al., 2014).

\footnotetext{
* Corresponding author: rajkoroljic@gmail.com

A significance of morphometric study of crayfish from the A. astacus species is justified by the fact that it is autochthonous European species being on the IUCN list of endangered species. According to IUCN criteria the said species was assigned to the VU (Vulnerable) category for the European region (Edsman et al., 2010) and is listed on the national Red List of Bosnia and Herzegovina as vulnerable species.

This study aims to determine variability of selected morphometric features of male and female specimens of the Noble crayfish from the Balkana Lake in Mrkonjic Grad.

\section{MATERIALS AND METHODS}

The Tourist and Recreational Center "Balkana" is located in the northwest of the Municipality of Mrkonjic Grad, 4-5 km away from the city and next to the motorway Jajce- Mrkonjic Grad-Bihac (formerly known as the "AVNOJ road"). It is situated at $750 \mathrm{~m}$ above sea level, in the foothill of the Lisina Mountain (1.650 $\mathrm{m}$ altitude).

What makes this complex very special are the Balkana Lakes at the altitude of $750 \mathrm{~m}$. Surface of the small lake (downstream) is $10.800 \mathrm{~m}^{2}$ and surface of the big lake (upstream) is $42.300 \mathrm{~m}^{2}$ (Figure 1, 2). The lakes were formed by natural depression which volume increased when a dam was constructed. The lake is separated in two parts by a lateral embankment. Principal filling of the lake is made by two smaller watercourses (Cijepalo from the right side composed of two springs - the Kovacko and Lazino spings from the left side of the thermal spring) that flows into the Big Lake and airfoil spring at 
the bottom of the Big Lake. The Crna Rijeka river flows out from the Lake (Crnogorac et al., 2013).

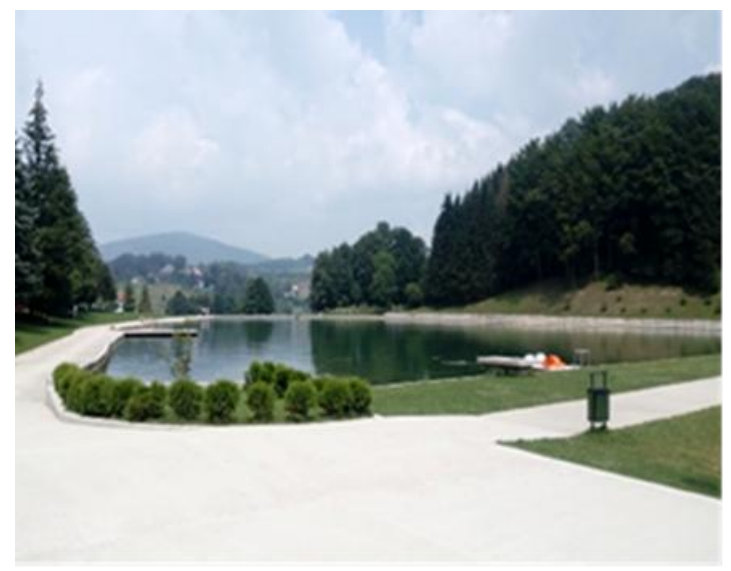

Figure 1. The Small Lake of Balkana.

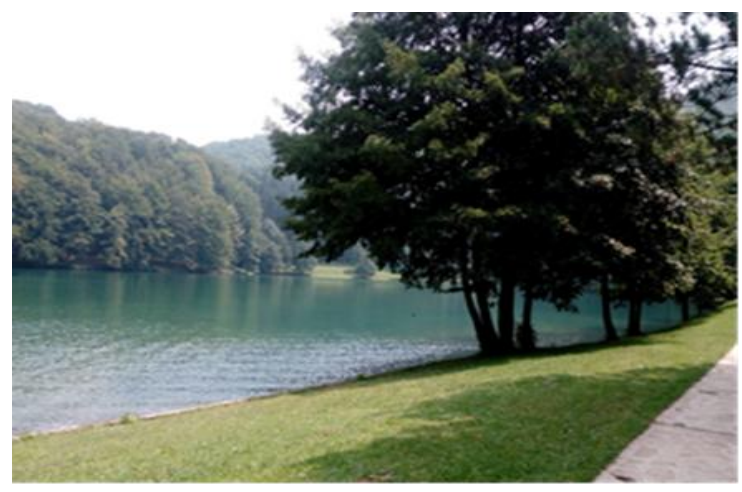

Figure 2. The Big Lake of Balkana.

Field studies were conducted in the period from October 9, 2018 until May 31, 2019. Sampling period included three seasons of crayfish activity: autumn, winter and spring. Sampling was carried out in two locations - one location was in the Malo jezero lake and the other location was the Veliko jezero lake. Crayfish were sampled with baited LiNi traps (Westman et al., 1978). We left traps overnights and collected crayfish the next morning. Then, 58 crayfish specimens were collected. Time of collection, apparent physical defects, signs of illness and parasites were recorded for each specimen. Afterwards, sex was determined for each collected specimen and morphometric features were measured.

Morphometric features such as: total body length (TBL), claw length (CLL), carapace length (CPL), carapace width $(\mathrm{CPW})$, abdomen length (ABL), rostrum length (ROL), rostrum width (ROW) and values of body weight $(\mathrm{W})$ were analyzed.

The fit/fitness coefficient was also calculated: Fulton's Conditions Factor (Ricker, 1975) and Crayfish Constant (Adegboye, 1981).

Fulton's Conditions Factor (FCF):

$$
F C F=\frac{W}{T B L^{3}}
$$

Where: $\mathrm{W}$ - total weight, TBL - total length

Crayfish Constant (CC):

$$
C C=\frac{W}{T B L \times C P L \times C P W}
$$

Where: W - total weight, TBL - total length, CPL - carapace length, CPW- carapace width (Streissl \& Höld, 2002).

Each specimen was measured with caliper to the nearest $0.02 \mathrm{~mm}$ and weight to the nearst $0.01 \mathrm{~g}$ with technical balance (type 'Kern' PFB Version 2.2). Obtained values of morphometric features were processed statistically (minimum, maximum, mean value, standard deviation and variation coefficient) by applying statistical program Microsoft Office Excel 2007, interpreted and compared to available data from related literature.

Database with photos was created and each specimen was captured from dorsal and ventral side. Such photos can serve to analyze body color and to identify re-collected specimen.

\section{RESULTS}

There were 58 analyzed specimens of which 38 (in particular $65.52 \%$ ) were male and 20 (in particular $34.48 \%$ ) were female (sex ration close to $1.9: 1$ ) (Figure 3 ).

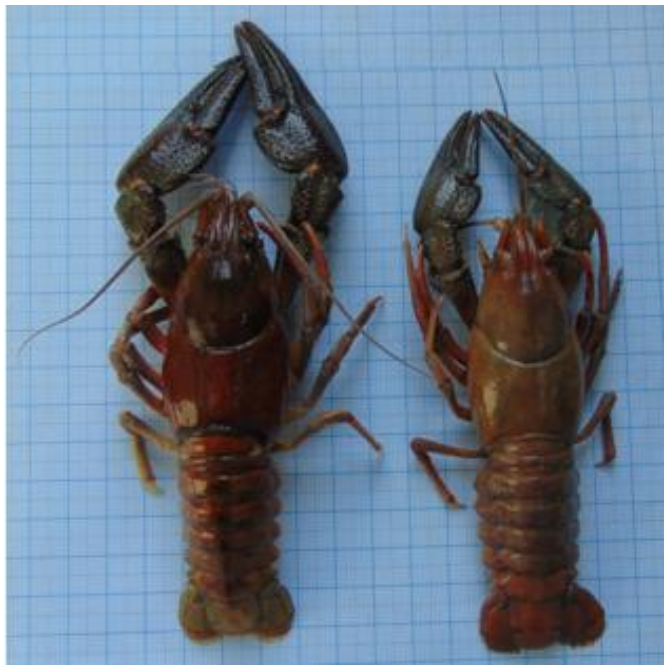

Figure 3. Astacus astacus - noble crayfish (male left, female right).

Measurement results of morphometric parameters of the Noble crayfish specimen from the Balkana Lake are given in tables as mean value, minimum (min), maximum (max), standard deviation (SD) and coefficient of variation (CV) (Table 1,2).

The values obtained for male specimens show that the average body weight was $27.99 \mathrm{~g}$, an average body length was $85.57 \mathrm{~mm}$, the claw length was $36.25 \mathrm{~mm}$, the cephalothorax length was $41.57 \mathrm{~mm}$, the carapace width was $23.94 \mathrm{~mm}$, the abdomen length was $36.78 \mathrm{~mm}$, the rostrum length was 11.19 $\mathrm{mm}$ and the rostrum width was $5.5 \mathrm{~mm}$. Based on these values, 
the standard deviation (SD) was obtained and had the highest value for body length (17.46), slightly smaller value for the total body length (17.2), the claw length (9.63), the abdomen length (9.03), the cephalothorax length (7.82), the carapace width was (5.82), and the least value was for the rostrum length (2.75) and width (0.38). The only steady feature at male specimens (CV < $10 \%)$ showed a morphometric feature (ROW) $(\mathrm{CV}=6.87 \%)$. CFL $(\mathrm{CV}=18.8 \%)$ falls into a low variable $(10 \%-20 \%)$. Most of the analyzed morphometric features were moderately variable (CV 20\% - 30\%, Table 1). Morphometric feature $\mathrm{W}(\mathrm{CV}=$ $62.37 \%$ ) at male specimens is the only feature that shows high variability $(\mathrm{CV}>30 \%)$ (Table 1$)$.

Table 1. Descriptive statistics - mean value, standard deviation, ranges of measured morphometric characteristics for males of species Astacus astacus from the Balkana lake.

\begin{tabular}{|l|c|c|c|c|c|}
\hline $\begin{array}{l}\text { Statistical } \\
\text { parameters }\end{array}$ & Mean & Min & Max & SD & CV \\
\hline W & 27.99 & 5.8 & 72 & 17.46 & 62.37 \\
\hline TBL & 85.77 & 56.35 & 114.14 & 17.2 & 20.1 \\
\hline CLL & 36.25 & 18.8 & 56.71 & 9.36 & 26.56 \\
\hline CFL & 41.57 & 28.16 & 51.79 & 7.82 & 18.8 \\
\hline CPW & 23.94 & 13.7 & 39.1 & 5.82 & 24.3 \\
\hline ABL & 36.78 & 18.9 & 43.37 & 9.03 & 24.55 \\
\hline ROL & 11.19 & 7.39 & 15.81 & 2.75 & 24.54 \\
\hline ROW & 5.5 & 5.08 & 6 & 0.38 & 6.87 \\
\hline
\end{tabular}

The values obtained for female specimens show that the average body weight was $17.09 \mathrm{~g}$, an average body length was $74.34 \mathrm{~mm}$, the claw length was $24.81 \mathrm{~mm}$, the cephalothorax length was $31.34 \mathrm{~mm}$, the carapace width was $18.56 \mathrm{~mm}$, the abdomen length $32.15 \mathrm{~mm}$, the rostrum length was $11.54 \mathrm{~mm}$ and the rostrum width was $5.46 \mathrm{~mm}$.

Based on these values, the standard deviation (SD) had the highest value for the total body length (16.38) and the body weight (11.54), slightly smaller for the abdomen length (8.78), the cephalothorax length (8.0), the claw width (6.64) and the carapace width (4.64) while the least value was for the rostrum length (1.99) and the width (0.58). The observed morphometric features are moderately variable (CV 20\% - 30\%), while a morphometric feature $\mathrm{W}(\mathrm{CV}=63.17 \%)$ was the only highly variable $(\mathrm{CV}>30 \%)$. None of analyzed features (Table 2 ) was a steady morphometric feature in female samples (CV < 10\%).

Males and females differ significantly $(\mathrm{p}<0.05)$ in five morphometric features $\mathrm{W}(\mathrm{p}=0.009)$, TBL $(\mathrm{p}=0.013)$, CLL ( $p$ $=0.000), \operatorname{CFL}(p=0.025)$ and CPW $(p=0.001)$ (Table 3$)$. There is no statistically significant difference $(p>0.05)$ for ABL $(p=$ 0.195 , ROL $(\mathrm{p}=0.403)$ and ROW ( $=0.441)$ (Table 3). By comparing the mean values of the abdomen length and rostrum width and length among the sexes, the Noble crayfish males have a higher mean value for the previously mentioned morphometric features compared to females, but that difference is not significant in statistical terms.
Table 2. Descriptive statistics - mean value, standard deviation, ranges of measured morphometric characteristics for females of species Astacus astacus from the Balkana lake.

\begin{tabular}{|l|c|c|c|c|c|}
\hline $\begin{array}{l}\text { Statistical } \\
\text { parameters }\end{array}$ & Mean & Min & Max & SD & CV \\
\hline W & 17.09 & 6.5 & 48 & 11.54 & 67.5 \\
\hline TBL & 74.34 & 46.1 & 105.6 & 16.38 & 22.03 \\
\hline CLL & 24.81 & 12.24 & 37.44 & 6.64 & 26.75 \\
\hline CFL & 31.34 & 19.19 & 40.8 & 8.0 & 25.52 \\
\hline CPW & 18.56 & 11.6 & 26.4 & 4.64 & 25.02 \\
\hline ABL & 32.15 & 17.92 & 41.47 & 8.78 & 27.3 \\
\hline ROL & 11.54 & 8.55 & 14.0 & 1.99 & 17.25 \\
\hline ROW & 5.46 & 4.4 & 6.0 & 0.58 & 10.66 \\
\hline
\end{tabular}

Table 3. Significance of differences between mean values of morphometric characteristics of crayfish species Astacus astacus from the Balkana lake.

\begin{tabular}{|c|c|c|c|c|c|}
\hline No. & Character & $\mathrm{P}$ & No. & Character & $\mathrm{p}$ \\
\hline 1. & $\mathrm{~W}$ & 0.009409 & 5. & CPW & 0.000586 \\
\hline 2. & TBL & 0.012641 & 6. & ABL & 0.19451 \\
\hline 3. & CLL & 0.000016 & 7. & ROL & 0.402779 \\
\hline 4. & CFL & 0.024528 & 8. & ROW & 0.44076 \\
\hline
\end{tabular}

The correlation between total body length and weight of males $(90.43 \%)$ and females $(81.68 \%)$ was calculated (Figure 4 ). Which shows that body weight increases as the body length increases.

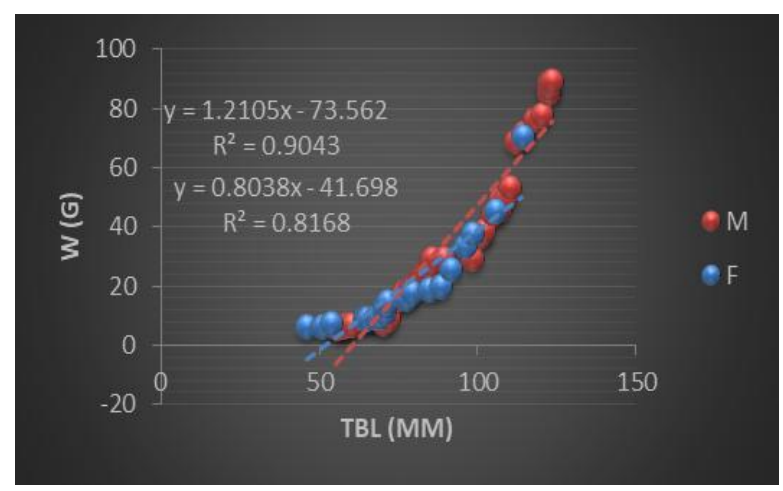

Figure 4. The ratio of body length and body weight of males and females of Noble crayfish.

The correlation between body weight and the claw length in both males, females is made and we notice a positive correlation, which means that the claw growth accompanies the body weight. The correlation coefficient is $93.42 \%$ in males and 93.14\% in females (Figure 5).

Based on the correlation coefficient by applying regression analysis, it is observed that the coefficient is highly significant in statistical terms between the carapace width and the body length. The correlation coefficient is $97.76 \%$ and $92.2 \%$ in females (Figure 6). 


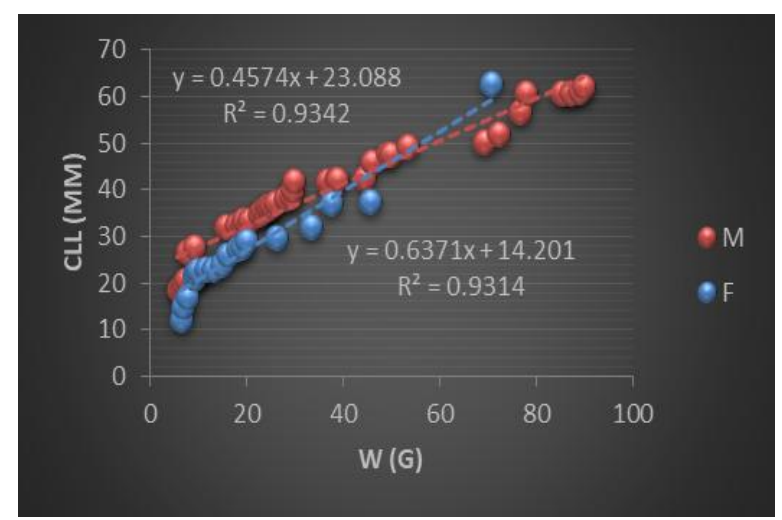

Figure 5. Relation of body weight and claw length in males and females of Noble crayfish.

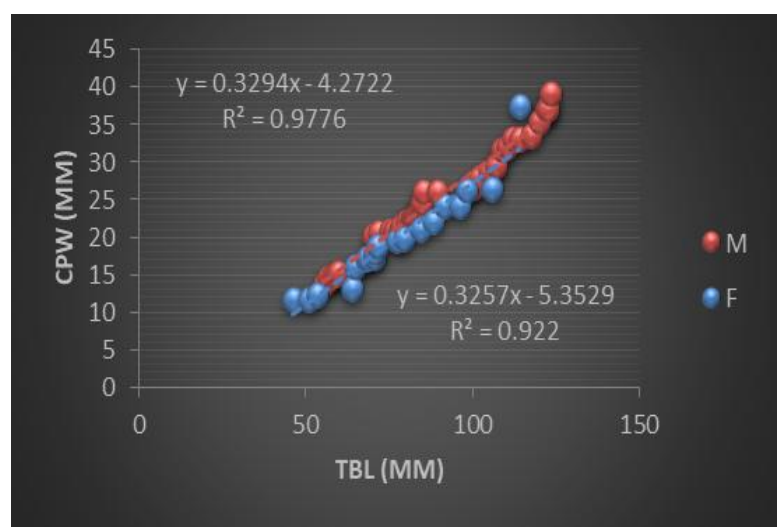

Figure 6. The ratio of body length and width of a carapace in males and females of Noble crayfish.

The least $\mathrm{CC}$ is 0.228 and the highest $\mathrm{CC}$ is 0.401 (for females). The mean value is 0.309 for females and 0.386 for males. The least FCF is 0.022 and the highest is 0.039 (for females). The mean value is 0.029 for females and 0.037 for males (Table 4).

Table 4. Values for condition factor for Noble crayfish specimen.

\begin{tabular}{|c|c|c|c|c|c|}
\hline $\begin{array}{c}\text { Statistical } \\
\text { parameters }\end{array}$ & \multicolumn{5}{|c|}{ FCF } \\
\hline Sex & Mean & Min & Max & SD & CV \\
\hline M & 0.037 & 0.026 & 0.055 & 0.011 & 30.91 \\
\hline F & 0.029 & 0.022 & 0.039 & 0.007 & 22.64 \\
\hline $\begin{array}{l}\text { Statistical } \\
\text { parameters }\end{array}$ & \multicolumn{5}{|c|}{ CC } \\
\hline Sex & Mean & Min & Max & SD & CV \\
\hline M & 0.386 & 0.272 & 0.488 & 0.09 & 24.41 \\
\hline F & 0.309 & 0.228 & 0.401 & 0.066 & 21.47 \\
\hline
\end{tabular}

\section{DISCUSSION}

Sex ration between male and female was 1.9:1 (males : females). A higher degree of male presence in the sample can be correlated with the fact that five female specimens with brooding eggs were sampled during the study period, pointing out to a season of a lower female activity (Rajkovic, 2012). Having information on the sex ratio in population is significant because it tells us about the health and stability of the population (Jurkovic, 2016)

Population of the noble crayfish at the observed location has relatively stable age structure. At the explored location on the Balkana Lake, the largest group was $101-120 \mathrm{~mm}$ long with a $60 \%$ share in population. The longest male body was 114.4 $\mathrm{mm}$, and the longest female body was $105.6 \mathrm{~mm}$ that corresponds to the range from 80 to $120 \mathrm{~mm}$ applicable to the Noble crayfish mentioned in the related literature (Obradovic, 1988), and values recorded by Trozic-Borovac et al. (2012b) and Rajkovic (2012). The heaviest male was $72 \mathrm{~g}$ and the heaviest female was $48 \mathrm{~g}$. The higher average male weight can be attributed to the fact that males has bigger claws that contributes to their higher body weight compared to females (Jurkovic, 2016).

Morphometric features of males and females from the $A$. astacus species found in the Balkana Lake considerably differ in statistical terms $(\mathrm{p}<0.05)$, where higher mean values were noticed for most of male features (Table 3). Obtained results can be correlated with the expressed sex dimorphism of crayfish from this species, where males are bigger than females (TrozicBorovac et al., 2012b; Rajkovic, 2012).

According to values of calculated factors we notice that males are more fit. A study of the Noble crayfish specimen fit factor in the Praca river supports the foregoing (Trozic-Borovac et al., 2012b).

\section{CONCLUSION}

Morphometric features of the Noble crayfish (Astacus astacus) in the Balkana Lake were monitored.

Seven morphometric features and two fit factors were analyzed on all 58 specimens (38 males and 20 females).

Obtained values for morphometric features of the Noble crayfish in the area of Mrkonjic Grad partially match the known scope of variability and represent first data for the investigated area.

Presence of statistically significant difference among adult specimens in body mass, total body length, the claw length, the cephalothorax length and the carapace width at males compared to females is justified by emphasized sex dimorphism in the Noble crayfish.

Data presented in this paper can serve as a basis for further research of Astacus astacus in this area.

\section{ACKNOWLEGMENTS}

The paper presents the result achieved by realization of Program for the conservation and sustainable use of genetic resources of Republic of Srpska, financed by the Ministry of 
Scientific and Technological development, Higher Education and Information Society performs of the Republic of Srpska and implemented by the Institute of Genetic Resources of the University of Banja Luka.

Expert opinion on the research of biodiversity was issued by the Republic Institute for the Protection of Cultural, Historical and Natural Heritage (No. 30 / 625-723 / 18, 09.10. 2018th year; number 07/1.30/625-020/19, dated 23.1. 2019).

\section{REFERENCES}

Crnogorac, C., Trbic, G., Rajcevic, V., Dekic, R., Pesevic, D., Lolic, S., Milosevic A., \& Celebic, M. 2013. Rijecna mreza opstine Mrkonjic Grad - fizickogeografska i ekoloska istrazivanja. Geografsko drustvo Republike Srpske, 147.

Edsman, L., Füreder, L., Gherardi, F., \& Souty-Grosset, C. 2010. Astacus astacus. The IUCN Red List of Threatened Species 2010: e.T2191A9338388. Downloaded on 24 October 2019.

Jurkovic, T. 2016. Populacijske znacajke potocnog raka Austropotamobius torrentium (Schrank, 1803) u potoku Dolje. Diplomski rad, Prirodoslovno-matematicki fakultet Sveucilista u Zagrebu, 50.

Maguire, I. 2010.Slatkovodni rakovi, Prirucnik za inventarizaciju i pracenje stanja. Drzavni zavod za zastitu prirode, Zagreb, 44.

Maguire, I., \& Gottstein-Matocec, S. 2004. The distribution pattern of freshwater crayfish in Croatia. Crustaceana, 77(1), pp. 25-47. doi: 10.1163/156854004323037874

Obradovic, J. 1988. Slatkovodni rakovi. Ribar. Jugoslavija, 43, pp. 55-59.

Rajkovic, M. 2012. Distribucija, filogenija, ekologija i konzervacija rakova iz familije Astacidae na podrucju Crne Gore. Doktorska disertacija. Prirodno-matematicki fakultet, Univerzitet u Kragujevcu.
Simic, V., Petrovic, A., Rajkovic, M., \& Paunovic, M. 2008. Crayfish of Serbia and Montenegro - The population status and the level of endangerment. Crustaceana, 81, pp. 11531176. doi: $10.1163 / 156854008 \times 374496$

Streissl, F., \& Hödl, W. 2002. Growth, morphometrics, size at maturity, sexual dimorphism and condition index of Austropotamobius torrentium Schrank. Hydrobiologia, 477, pp. 201-208. doi: 10.1023/A:1021046426577

Trozic-Borovac, S 2011. Freshwater crayfish in Bosnia and Herzegovina: the first report on their distribution. Knowledge and Management of Aquatic Ecosystems, 401, pp. 26. doi: $10.1051 / \mathrm{kmae} / 2011048$

Trozic-Borovac, S., Deljanin, L., \& Dautbasic, M. 2007. Ekolosko-biosistematske karakteristike potocnog raka Austropotamobius torrentiumm (Shrank, 1803.) iz Nahorevskog potoka, Radovi Sumarskog fakulteta, Univerzitet u Sarajevu, pp. 39-55.

Trozic-Borovac, S., Macanovic, A., \& Skrijelj, R. 2012a. The morfometrics characterics and condition index of Austropotamobius pallipes in the Neretva river basin. Works of the Faculty of Forestry, University of Sarajevo, 2, pp. 13 30.

Trozic-Borovac, S., Nuhefendic, I., Gajevic, M., \& Imamovic, A. 2012b. Morphometrics characters of Astacus astacus L.(Astacidae) from the Praca river. Works of the Faculty of Forestry University of Sarajevo, 1, pp. 1-10.

Vukovic, T., N . Guzina, N., Vukovic, D, Seratlic, E. Durovic., \& Sofradzija. A. 1978. Problemi razvoja biosistematskih istrazivanja slatkovodnih riba u Bosni i Hercegovini. Godisnjak Bioloskog Instituta Univerziteta u Sarajevu, 31, pp. 207-211.

Westman K., Pursiainen M., \& Vilkman R. 1978. A new folding trap model which prevents crayfish from escaping. Freshwater Crayfish, 4, pp. 235-242.

Zivic, V. N., Atanackovic, A., Milosevic, S., \& Milosavljevic, M. 2014. The distribution of Astacidae (Decapoda) fauna in Kosovo and Metohija. Water Research and Management, 4(4), pp. 35-40. 